\section{Thirty-Cycle Tempera- ture Optimization of a Closed-Cycle Capillary PCR Machine}

BioTechniques 33:557-564 (September 2002)

\begin{abstract}
The performance of a novel thermal cycler has been characterized in a 30-cycle PCR. The device consists of a microcapillary equipped with bidirectional pressure-driven flow and in situ optical position sensors. A 1$\mu L$ droplet of reaction mixture moves between three heat zones in a 1-mm i.d., oilfilled capillary using a multi-element scattered light detector and active feedback. The design permits time and number of cycles to be changed without hardware modification, unlike other flow-in-capillary PCR systems. Temperature optimization has been performed on the three PCR heat steps. The optimal denaturation temperature is $94^{\circ} \mathrm{C}-96^{\circ} \mathrm{C}$, which is identical to commercial machines. The optimal extension temperature of $62^{\circ} \mathrm{C}-66^{\circ} \mathrm{C}$ is lower than reported for Taq DNA polymerase $\left(70^{\circ} \mathrm{C}-80^{\circ} \mathrm{C}\right)$ because of the high enzyme concentration and/or the absence of detergent in the PCR mixture. The optimal annealing temperature seems to be the same as the optimal extension temperature. This is because extension occurs when the sample is inside of the annealing heat zone. Annealing takes place as the sample travels between heat zones. Device speed (23 min for 30 cycles without time optimization) is competitive with other rapid PCR designs for efficiencies comparable to a commercial machine.
\end{abstract}

\section{INTRODUCTION}

PCR is arguably the single most important molecular biology technique developed in the last 20 years. PCR has historically been performed in a computer-controlled heat block, where a large portion of the reaction time is spent heating and cooling. Many alternative machine configurations have been developed to shorten the reaction time by minimizing temperature transition times $(5-9,11,12,15,17,20)$. We previously described (4) a novel PCR machine design. The device consists of a microcapillary equipped with bidirectional pressure-driven flow and in situ optical position sensors. A $1-\mu \mathrm{L}$ droplet of reaction mixture moves between three heat zones in a 1-mm i.d., oil-filled capillary using a multi-element scattered light detector and active feedback. The three heat zones correspond to the three stages of PCR and are heated to the denaturing, extension, and annealing temperatures $\left(T_{D}, T_{E}\right.$, and $T_{A}$, respectively). The design permits time and number of cycles to be changed without hardware modification, unlike other flow-in-capillary PCR systems $(9,12)$. Here we report 30 -cycle PCR results for our device. It is competitive with the fastest devices reported in the literature for comparable efficiency. Comparable efficiency is an important point, since PCR efficiency drops as speed increases.

\section{MATERIALS AND METHODS}

Here we utilize realistic, 30-cycle PCR to characterize our device thoroughly. Our PCR mixture includes 1.9 fM $\lambda$ phage DNA (USB, Cleveland, $\mathrm{OH}$, USA); two primers, each $600 \mathrm{nM}$, which define a 500-bp target (5'-GATGAGTTCGTGTCCGTACAACTG-3' and $5^{\prime}$-GGTTATCGAAATCAGCCACAGCGC-3'; custom manufactured by Invitrogen, Carlsbad, CA, USA); approximately $0.7 \mathrm{U} / \mu \mathrm{L} T a q$ DNA polymerase (purified from a standard mixture from Promega, Madison, WI, USA); $300 \mu \mathrm{M}$ each of the four dNTPs (Amersham Biosciences, Piscataway, NJ, USA); $50 \mathrm{mM} \mathrm{KCl} ; 10 \mathrm{mM}$ Tris$\mathrm{HCl}\left(\mathrm{pH} 9.0\right.$ at $25^{\circ} \mathrm{C}$ ); and $2 \mathrm{mM}$ $\mathrm{MgCl}_{2}$. A 50- $\mu \mathrm{L}$ sample of the mixture was formulated at the beginning of each trial and kept on ice.

There are two significant abnormalities in our PCR mixture. First, we used a much higher concentration of Taq DNA polymerase to counter its adsorption to the capillary walls. Second, we removed the Triton ${ }^{\circledR}$ X-100 from the Promega Taq DNA polymerase mixture before use via centrifugal concentration. It is not suitable in our application 
since it is a detergent-it would destroy the plug/oil surface tension. Following concentration, the end volume varied between 40 and $80 \mu \mathrm{L}$, which accounts for the ambiguity in Taq DNA polymerase concentration.

Passivating the tubes with BSA and using a normal quantity of Taq DNA polymerase $(0.02 \mathrm{U} / \mu \mathrm{L})$ were unsuccessful. BSA $(0.5 \mathrm{mg} / \mathrm{mL})$ reduced the droplet surface tension enough to cause it to break up. BSA $(0.05,0.1$, and 0.2 $\mathrm{mg} / \mathrm{mL}$ ) did not produce breakup but also did not prevent Taq DNA polymerase adsorption to the sidewalls. The same result occurred with tubes siliconized with $5 \%$ dichlorodimethylsilane in heptane.

A new capillary was used for each run, which took approximately $23 \mathrm{~min}$ to complete. There was only several seconds' time variation between runs. Each trial used sample droplets drawn from the same aliquot to maximize uniformity. Runs in a given trial were performed sequentially as quickly as possible.

Each trial had two control reactions performed using $10-\mu \mathrm{L}$ volumes of the same mixture in a Robocycler ${ }^{\circledR}$ Gradient 96 (Stratagene, La Jolla, CA, USA). Cycling consisted of 30 cycles of denaturation at $94^{\circ} \mathrm{C}$ for $30 \mathrm{~s}$, followed by annealing at $53^{\circ} \mathrm{C}$ for $45 \mathrm{~s}$, and extension at $70^{\circ} \mathrm{C}$ for $30 \mathrm{~s}$. The first denaturation was $8 \mathrm{~min}$ long, and the final extension was 7.5 min long.

DNA concentration was determined via electrophoresis on $2 \%$ agarose gels, followed by staining with 1:10000
SYBR ${ }^{\circledR}$ Green I (Molecular Probes, Eugene, OR, USA) in TBE and quantification against mass standards using a Gel-Doc ${ }^{\mathrm{TM}} 1000$ System (Bio-Rad Laboratories, Hercules, CA, USA).

\section{RESULTS AND DISCUSSION}

The heating schedule consisted of 30 cycles of denaturing at $T_{D}$ for $5 \mathrm{~s}$, followed by annealing at $T_{A}$ for $5 \mathrm{~s}$, and extension at $T_{E}$ for $30 \mathrm{~s}$. The initial denaturing step was $30 \mathrm{~s}$ long, and the final extension step was $60 \mathrm{~s}$ long. $T_{D}$, $T_{A}$, and $T_{E}$ were independently varied to find the optimal denaturation, annealing, and extension temperatures, respectively.

For the denaturation temperature optimization, $T_{D}$ was varied from $86^{\circ} \mathrm{C}$ to $96^{\circ} \mathrm{C}, T_{A}=53^{\circ} \mathrm{C}$, and $T_{E}=70^{\circ} \mathrm{C}$. Results (not shown) were as expected: little or no yield except at $T_{D}=94^{\circ} \mathrm{C}$ and $96^{\circ} \mathrm{C}$, when yield averaged $10-11$ $\mathrm{ng} / \mu \mathrm{L}$ (over three trials) for both. For denaturation, $94^{\circ} \mathrm{C}$ is almost universally used. Below $94^{\circ} \mathrm{C}$, denaturation efficiency decreases, and yield drops off. Above $94^{\circ} \mathrm{C}, \mathrm{Taq}$ DNA polymerase decay offsets the increased denaturation efficiency. This latter effect is not as marked in our device, since our denaturation times are very short. However, raising $T_{D}$ above $94^{\circ} \mathrm{C}$ did not increase yield. To avoid boiling, we did not test above $96^{\circ} \mathrm{C}$.

For the extension temperature optimization, $T_{D}=94^{\circ} \mathrm{C}, T_{A}=53^{\circ} \mathrm{C}$, and
$T_{E}$ was varied from $54^{\circ} \mathrm{C}$ to $78^{\circ} \mathrm{C}$. Results are shown in Figure 1. The optimal extension temperature for our system is $62^{\circ} \mathrm{C}-66^{\circ} \mathrm{C}$. This is lower than the $70^{\circ} \mathrm{C}-80^{\circ} \mathrm{C}$ optimal temperature reported for $T a q$ DNA polymerase (1). Experiments with the Robocycler Gradient 96 also produced this result. Therefore, the results are due to the unusual constituency of the PCR mixture itself: either the large Taq DNA polymerase concentration and/or the absence of Triton X-100.

For the annealing temperature optimization, $T_{D}=94^{\circ} \mathrm{C}, T_{A}$ was varied from $33^{\circ} \mathrm{C}$ to $68^{\circ} \mathrm{C}$, and $T_{E}=70^{\circ} \mathrm{C}$. Results are shown in Figure 2. While the data are inconclusive, Figure 2 suggests an optimal $T_{A}$ of $63^{\circ} \mathrm{C}-68^{\circ} \mathrm{C}$. Theory $(13,14)$ predicts optimal $T_{A}$ values of $52^{\circ} \mathrm{C}$ and $59^{\circ} \mathrm{C}$ for the two primers. $T_{A}$ for the reaction should fall between these two values. However, it was found to be higher-about the same as the optimal $T_{E}$.

This discrepancy is believed to be due to annealing occurring as the plug travels between heat zones. Thermal modeling of the fluid verified that the plug dips into the optimal annealing temperature for about a half-second during this travel. This is sufficient time for annealing to occur (18). Once the plug reaches the annealing zone, extension occurs. Since extension occurs in both the annealing and extension zones, the result is increased product. Of course, this occurs when $T_{A}$ is near the optimal $T_{E}$ range.

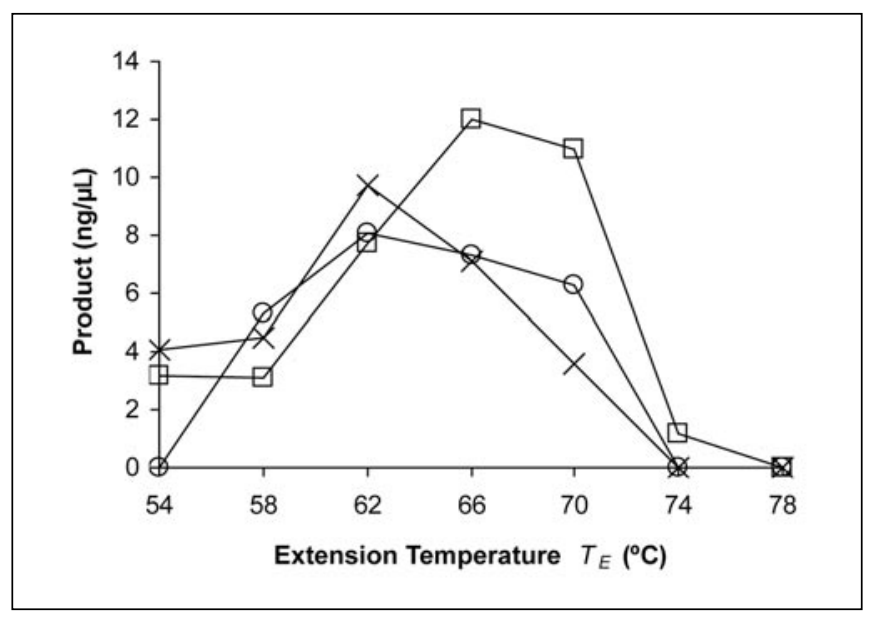

Figure 1. Results of the extension temperature optimization. $\square, \bigcirc$, and $\times$ represent three different trials. Positive controls: for $\square, 1.7$ and $1.9 \mathrm{ng} / \mu \mathrm{L}$; for $\bigcirc, 13$ and $18 \mathrm{ng} / \mu \mathrm{L}$; for $\times, 21$ and $29 \mathrm{ng} / \mu \mathrm{L}$.

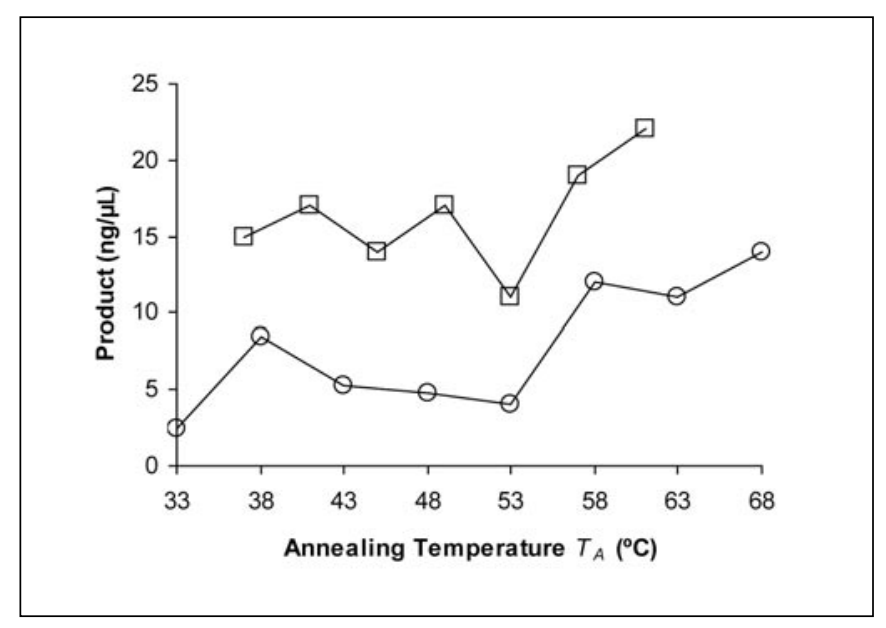

Figure 2. Results of the annealing temperature optimization. $\square$ and $\bigcirc$ represent two different trials. Positive controls: for $\square, 2.9$ and $3.6 \mathrm{ng} / \mu \mathrm{L}$; for $\bigcirc$, 1.7 and $1.9 \mathrm{ng} / \mu \mathrm{L}$. 


\section{Short Technical Reports}

Table 1. Performance Comparison of the Closed-Cycle Capillary PCR Machine against Other Fast PCR Machines from the Literature

\begin{tabular}{|c|c|c|c|c|c|}
\hline Machine & Template (M) & Target (bp) & $\begin{array}{l}\text { Time per } \\
\text { Cycle (s) }\end{array}$ & $\begin{array}{cc}\text { Efficiency } & \mathrm{T} \\
(\%) & \end{array}$ & $\begin{array}{l}\text { Time/(Cycle } \\
\times \text { bp) (s/bp) }\end{array}$ \\
\hline $\begin{array}{l}\text { Conventional } \\
\text { (typ.) }\end{array}$ & $5 \times 10^{-15}$ & $500-1000$ & 240 & 70 & $0.24-0.48$ \\
\hline Air Cycler (18) & $1.9 \times 10^{-15}$ & 536 & 80 & approximately 70 & 0.15 \\
\hline \multicolumn{6}{|l|}{ Silicon } \\
\hline Chambers (20) & $1.0 \times 10^{-16}$ & 297 & 32.5 & 91 & 0.11 \\
\hline $\begin{array}{l}\text { Flow-in- } \\
\text { Capillary (12) }\end{array}$ & $5.2 \times 10^{-11}$ & 1000 & 88 & 29 & 0.088 \\
\hline Chip (9) & $1.7 \times 10^{-11}$ & 176 & 56 & approximately 70 & 0.32 \\
\hline $\begin{array}{l}\text { Integrated } \\
\text { PCR/CE (11) }\end{array}$ & (5-6 molecules) & 136 & 30 & approximately 70 & 0.22 \\
\hline This work & $1.9 \times 10^{-15}$ & 500 & 46 & 74 & 0.092 \\
\hline
\end{tabular}

In addition to the temperature optimization, we also tested our device against the control machine in product variability. A total of nine data points from the three temperature optimizations $\left(T_{D}=94^{\circ} \mathrm{C}, T_{A}=53^{\circ} \mathrm{C}\right.$, and $T_{E}=$ $70^{\circ} \mathrm{C}$ for all) was compared against the 10 positive controls used in these same reactions. The mean product for the capillary machine was $8.0 \mathrm{ng} / \mu \mathrm{L}$, with a standard deviation of $3.1 \mathrm{ng} / \mu \mathrm{L}$ (39\% of the mean). The mean product for the control machine was $10 \mathrm{ng} / \mu \mathrm{L}$, with a standard deviation of $9.5 \mathrm{ng} / \mu \mathrm{L}$ ( $95 \%$ of the mean). The capillary PCR machine gives more uniform results, but with lower yield. However, the slightly lower product is a small trade off for the much faster thermal cycling. The results are for our high Taq DNA polymerase, no Triton X-100 PCR mixture.

Table 1 compares the closed-cycle capillary PCR machine against several rapid PCR machines described in the literature. The conventional PCR machine is the standard computer-controlled single heat block. The air cycler (16-18) uses convection heating to cycle the samples inside of small glass capillaries. It has evolved into the Roche LightCycler ${ }^{\mathrm{TM}}$ (Roche Applied Science, Indianapolis, IN, USA) (19). The silicon chambers (20) are miniature heat blocks, each made from a pair of bonded silicon pieces patterned with resistive heaters. Several versions of the device have been developed, one of the most recent of which is the Advanced Nucleic Acid Analyzer (2), a briefcase- sized machine with 10 independently controlled heat blocks. The flow-incapillary machine (12) pushes a $50-\mu \mathrm{L}$ sample through a Teflon ${ }^{\circledR}$ capillary coiled 30 times through three different temperature zones. This differs from our device primarily in that the 250$\mathrm{mm}$ sample plug crosses many heat zones simultaneously and the sample motion is unidirectional and continuous, rather than reciprocating and intermittent. Kopp et al. (9) miniaturized the concept onto a glass wafer. They etched a serpentine channel in glass that crossed three heat zones each 20 times. The integrated PCR/capillary electrophoresis (CE) (11) is a glass wafer with eight PCR channels lithographically etched into it, each feeding a CE channel for subsequent diagnostics. When a device was about as efficient as a conventional heat block machine with no further quantification, its efficiency $Y$ was assumed to be approximately $70 \%$. This is typical for a conventional heat block machine (3). Efficiency is defined as

$$
\frac{\text { concentration of product }}{\text { concentration of template }}=(1+Y)^{n}
$$
where $n$ is the number of cycles, and concentration refers to the molar concentration.

The objective of this research was to produce a PCR machine to amplify a sample over 30 cycles in as little time as possible with efficiency comparable to that of commercial machines. Table 1 indicates that this goal has been accomplished fairly well. Note that the cycle time has not yet been optimized. The criterion used to compare machines is the time/cycle/target length (in bases). This is because, ideally, PCR time is dominated by extension time, which is proportional to product length and number of cycles.

It should be noted that the integrated PCR/CE device of Lagally et al. (11) was later shown to rapidly amplify a single molecule (10). In addition, it uses the smallest PCR volume (280 nL). Both are remarkable achievements.

A few qualifiers should be mentioned. $Y=70 \%$ and $n=30$ are typical values in a commercial PCR machine reaction (3). There are examples in the literature of significantly faster cycle times. However, to our knowledge, they either did not have $Y \geq 70 \%$ or did not have $n \geq 30$. There is a direct trade off between $Y$ and reaction speed (For examples, see References 9 and 12).

A notable example is presented by Kopp et al. (9). They performed 20-cycle PCR at various speeds, producing detectable product in as little as $90 \mathrm{~s}$. However, none of their runs was as efficient as their control machine, which in the absence of other information is assumed to have $Y$ equal to approximately $70 \%$. Their longest (18.7-min) run produced the most product; hence, it is the only run listed in Table 1. It is possible that more product would be generated by longer run times.

Another notable example is presented by Belgrader et al. (2). Their PCR cycle time is $17 \mathrm{~s}$. It is difficult to evaluate their results, since neither the end concentration nor the length of the PCR product is stated. Each 10 -fold dilution of template (from 500 to 50 and 5 initial cells) resulted in a three- or four-cycle increase to detect product, implying a very high $Y$. However, this applies to the early cycles in which the DNA from five or 50 initial cells are catching up to the amount of DNA in 500 cells. $Y$ is typically very high if only the initial cycles are taken into account. In later cycles, $Y$ drops since the number of DNA molecules exceeds the number of Taq DNA polymerase molecules, and DNA re-annealing competes with primer annealing. The heating and cooling rates for the device $\left(6.5^{\circ} \mathrm{C} / \mathrm{s}\right.$ and $4.3^{\circ} \mathrm{C} / \mathrm{s}$, respectively) are modest and account for the entire $17-\mathrm{s}$ cycle. This is marginally 
faster than the earlier version (20) listed in Table 1. The experiments with the earlier version had $20 \mathrm{~s}$ of temperature transition per cycle. Therefore, it is assumed that the more recent device would compare comparably against our device under similar conditions.

Giordano et al. (6) report 12-s cycles for their polymeric microchip. However, $n=15$. Also, $Y$ is low. They do not produce as much product as a commercial heat block also using 2-s annealing, extension, and denaturation times. Commercial heat block machines are severely handicapped at these short times.

There are several difficulties that must be addressed before this device becomes commercially practical. First, the PCR mixture is nonstandard and must be specially formulated. It requires a large concentration of Taq DNA polymerase. We do not know if some capillary wall coating could eliminate this requirement. Also, Triton X-100 or any other detergent must be removed. This can make the mixture perform inconsistently. Second, the device can only handle a single sample of fixed $(1 \mu \mathrm{L})$ volume. Third, loading and unloading are currently performed manually. Finally, the PCR mixture can cool down enough to anneal between heat blocks.

In conclusion, a novel PCR device has been tested over 30 temperature cycles. Temperature optimization has been performed for each of the three PCR heat steps. The denaturation optimum temperature is the standard $94^{\circ} \mathrm{C}-96^{\circ} \mathrm{C}$. Extension shows an optimal temperature of $62^{\circ} \mathrm{C}-66^{\circ} \mathrm{C}$, which is lower than the $70^{\circ} \mathrm{C}-80^{\circ} \mathrm{C}$ reported for Taq DNA polymerase. This is due to either the large concentration of Taq DNA polymerase and/or the absence of Triton X-100 in our PCR mixture. The results suggest that annealing and extension have the same optimal temperature range. This is due to the plug annealing as it passes be- tween heat blocks and extends inside of the annealing block. The machine is shown to be competitive with other rapid PCR designs in terms of reaction speed for efficiency comparable to a commercial machine over 30 cycles.

In the future, device speed could be increased in a number of ways. Time optimization can reduce the time required by each heat step. The plug can be shuttled faster between blocks, theoretically until it starts to break into pieces. The design can also be scaled down, reducing the time the plug spends both traveling between blocks and heating/cooling (4).

\section{REFERENCES}

1.Bej, A.K. and M.H. Mahbubani. 1994. Thermostable DNA polymerases for in vitro DNA amplifications, p. 219-237. In H.G. Griffin and A.M. Griffin (Eds.), PCR Technology: Current Innovations. CRC Press, Boca Raton, FL.

2.Belgrader, P., W. Benett, D. Hadley, J. 
Richards, P. Stratton, R. Mariella, Jr., and F. Milanovich. 1999. PCR detection of bacteria in seven minutes. Science 284:449-450.

3.Cha, R.S. and W.G. Thilly. 1995. Specificity, efficiency, and fidelity of PCR, p. 37-51. In C.W. Dieffenbach and G S. Dveksler (Eds.), PCR Primer: A Laboratory Manual. CSH Laboratory Press, Cold Spring Harbor, NY.

4.Chiou, J., P. Matsudaira, A. Sonin and D. Ehrlich. 2001. A closed-cycle capillary polymerase chain reaction machine. Anal. Chem. 73:2018-2021.

5.Friedman, N.A. and D.R. Meldrum. 1998. Capillary tube resistive thermal cycling. Anal. Chem. 70:2997-3002.

6.Giordano, B.C., J. Ferrance, S. Swedberg, A.F.R. Hühmer, and J.P. Landers. 2001 Polymerase chain reaction in polymeric microchips: DNA amplification in less than 240 seconds. Anal. Biochem. 291:124-132.

7.Hühmer, A.F.R. and J.P. Landers. 2000. Noncontact infrared-mediated thermocycling for effective polymerase chain reaction amplification of DNA in nanoliter volumes. Anal. Chem. 72:5507-5512.

8.Khandurina, J., T.E. McKnight, S.C. Jacobson, L.C. Waters, R.S. Foote, and J.M. Ramsey. 2000. Integrated system for rapid PCR-based DNA analysis in microfluidic devices. Anal. Chem. 72:2995-3000.

9.Kopp, M.U., A.J. de Mello, and A. Manz. 1998. Chemical amplification: continuousflow PCR on a chip. Science 280:1046-1048.

10.Lagally, E.T., I. Medintz, and R.A. Mathies. 2001. Single-molecule DNA amplification and analysis in an integrated microfluidic device. Anal. Chem. 73:565-570.

11.Lagally, E.T., P.C. Simpson, and R.A. Mathies. 2000. Monolithic integrated microfluidic DNA amplification and capillary electrophoresis analysis system. Sensors Actuators B 63:138-146.

12.Nakano, H., K. Matsuda, M. Yohda, T. Nagamune, I. Endo, and T. Yamane. 1994. High speed polymerase chain reaction in constant flow. Biosci. Biotechnol. Biochem. 58:349-352.

13.Wetmur, J.G. 1991. DNA probes: applications of the principles of nucleic acid hybridization. Crit. Rev. Biochem. Mol. Biol. 26:227-259.

14.Wetmur, J.G. and N. Davidson. 1968. Kinetics of renaturation of DNA. J. Mol. Biol. 31:349-370.

15.Wilding, P., M.A. Shoffner, and L.J. Kricka. 1994. PCR in a silicon microstructure. Clin. Chem. 40:1815-1818.

16.Wittwer, C.T., G.C. Fillmore, and D.J. Garling. 1990. Minimizing the time required for DNA amplification by efficient heat transfer to small samples. Anal. Biochem. 186:328331 .

17.Wittwer, C.T., G.C. Fillmore, and D.R. Hillyard. 1989. Automated polymerase chain reaction in capillary tubes with hot air. Nucleic Acids Res. 17:4353-4357.

18.Wittwer, C.T. and D.J. Garling. 1991. Rapid cycle DNA amplification: time and temperature optimization. BioTechniques 10:76-83.

19.Wittwer, C.T., K.M. Ririe, R.V. Andrew, D.A. David, R.A. Gundry, and U.J. Balis. 1997. The LightCycler ${ }^{\mathrm{TM}}$ : a microvolume multisample fluorimeter with rapid temperature control. BioTechniques 22:176-181.

20.Woolley, A.T., D. Hadley, P. Landre, A.J. deMello, R.A. Mathies, and M.A. Northrup. 1996. Functional integration of PCR amplification and capillary electrophoresis in a microfabricated DNA analysis device. Anal. Chem. 68:4081-4086.

This research was supported by the $\mathrm{Na}$ tional Institutes of Health grant no. HG01389 and the Air Force Office of Scientific Research grant no. F49620-98-1-0235. Address correspondence to Dr. Daniel J. Ehrlich, Whitehead Institute, Room 661, 9 Cambridge Center, Cambridge, MA 02142, USA.e-mail: ehrlich@wi.mit.edu

Received 3 April 2002; accepted 31 May 2002.

Jeffrey T. Chiou, Paul T. Matsudaira, and Daniel J. Ehrlich Whitehead Institute

Cambridge, MA, USA

\section{Linear Amplification of Catalyzed Reporter Deposition Technology on Nylon Membrane Microarray}

BioTechniques 33:564-570 (September 2002)

\section{ABSTRACT}

The application of microarray analysis to gene expression from limited tissue samples has not been very successful because of the poor signal quality from the genes expressed at low levels. Here we discussed the use of catalyzed reporter deposition (CARD) technology to amplify signals from limited RNA samples on nylon membrane cDNA microarray. When the input RNA level was greater than $10 \mu \mathrm{g}$, the genes expressed at high levels did not amplify in proportion to those expressed at low levels. Compared to conventional colorimetric detection, the CARD method requires less than $10 \%$ of the total RNA used for amplification of signal displayed onto a nylon membrane cDNA microarray. Total RNA (5-10 $\mu \mathrm{g})$, as one can extract from a limited amount of specimen, was determined to produce a linear correlation between the colorimetric detection and CARD methods. Beyond this range, it can cause a nonlinear amplification of highly expressed and low-abundance genes. These results suggest that when amplification is needed for any applications using the CARD method, including DNA microarray experiments, precaution has to be taken in the amount of RNA used to avoid skew amplification and thus misleading conclusions.

\section{INTRODUCTION}

The microarray biochip enables life scientists to understand the mechanisms of diseases, develop new drugs and diagnostics, and widen the scope of basic research (16). The sensitive detection of low-abundance mRNA or limited tissue samples is almost impossible using direct labeling strategies. To improve signal detection in scarce biomedical specimens, we applied the catalyzed reporter deposition (CARD) technology (11), a signal amplification technique, to nylon microarrays. The signal output derived from the sequential tyramide amplification should reflect the transcriptional levels of all the genes in a linear fashion and avoid over- and underestimation of the original quantity.

RNA, especially mRNA, is the standard source for performing microarray experiments. However, this biological material is very limited in a number of cases (e.g., cancer samples and lowabundance transcripts from various tissue-specific genes). Thus, signal amplification methods become essential to generate meaningful and reliable data. Recently, a patented technology, Tyramide Signal Amplification ${ }^{\mathrm{TM}}\left(\mathrm{NEN}^{\circledR}\right.$ Life Science Products, Boston, MA, USA) (7-9), also known as the CARD method, has been developed. It amplifies both chromogenic and fluorescent signals in standard immunohistochemistry and in situ hybridization protocols, resulting in a significant increase in sensitivity, with no loss of resolution or an increase in background. This tyramide-based technique allows amplifi- 